\title{
Erratum to: Alkali/Surfactant Improved Low-Salinity Waterflooding
}

\author{
S. Shaddel · H. Mahani · S. A. Tabatabae-Nejad
}

Published online: 31 December 2014

C) Springer Science+Business Media Dordrecht 2014

\section{Erratum to: Transp Porous Med DOI 10.1007/s11242-014-0417-1}

Due to an imperative request from his employer to remove his name from this paper, one of the authors has agreed to dissociate himself from the paper. The Editor-in-Chief has given his approval for this change. Everything else in the paper remains correct.

The online version of the original article can be found under doi:10.1007/s11242-014-0417-1.

S. Shaddel $(\bowtie) \cdot$ S. A. Tabatabae-Nejad

Sahand Petroleum Research Center, Sahand University of Technology, Tabriz, Iran e-mail: s_shaddel@sut.ac.ir

H. Mahani

Shell Global Solutions Int, B.V., Kessler Park 1, 2288 GS Rijswijk, The Netherlands 